\title{
Topical hepatic hypothermia plus ischemic preconditioning. Analysis of bile flow and ischemic injuries after initial reperfusion in rats $^{1}$
}

\author{
Hipotermia hepática tópica mais pré-condicionamento isquêmico. Análise do fluxo biliar e \\ danos isquêmicos após a reperfusão inicial em ratos
}

\author{
Tomaz de Jesus Maria Grezzana FilhoI, Tais Burmann de Mendonça ${ }^{\mathrm{II}}$, Gémerson Gabiatti ${ }^{\mathrm{III}}$, Graziella Rodrigues ${ }^{\mathrm{IV}}$, Norma \\ Anair Possa Marroni ${ }^{\mathrm{V}}$, Lisiane Treis", Samanta Daiana De Rossi" ${ }^{\mathrm{II}}$, Carlos Otavio Corso ${ }^{\mathrm{VI}}$ \\ ${ }^{1}$ Research performed at the Experimental Surgical Center, Clinicas Hospital (HCPA), Federal University of Rio Grande do Sul (UFRGS), Porto \\ Alegre-RS, Brazil.

\begin{abstract}
${ }^{\mathrm{I}} \mathrm{PhD}$, Liver Transplantation Surgeon, HCPA, Department of Surgery, UFRGS, Porto Alegre-RS, Brazil. Conception and design of the study, analysis and interpretation of data, acquisition of data, manuscript writing.

${ }^{\text {II }}$ Graduate student, Scientific Initiation Program, Faculty of Medicine, UFRGS, Porto Alegre-RS, Brazil. Helped with technical procedures, collection of study informations and statistical analysis.

III Fellow PhD degree, Postgraduate Program of Surgical Sciences, UFRGS, Porto Alegre-RS, Brazil. Conception of the study and involved with technical procedures.

IV Biologist, Master, Postgraduate Program of Medical Sciences, UFRGS, Porto Alegre-RS, Brazil. Collection and processing of study informations and critical revision.

${ }^{\mathrm{v}} \mathrm{PhD}$, Physiologist, Postgraduate Program of Medical Sciences, Laboratory of Physiology, UFRGS, Porto Alegre-RS, Brazil. Analysis and interpretation of data, manuscript preparation.

${ }^{\mathrm{V}} \mathrm{PhD}$, Associate Professor, Department of Morphological Sciences, Postgraduate Program of Surgical Sciences, UFRGS, Porto Alegre-RS, Brazil. Tutor, responsible for intellectual and scientific content of the study.
\end{abstract}

\begin{abstract}
Purpose: To evaluate the effects of the topical liver hypothermia and IPC combination against I/R injury after initial reperfusion. Methods: In 32 Wistar rats, partial liver ischemia was induced for 90 minutes in normothermia (IN), ischemic preconditioning (IPC), $26^{\circ} \mathrm{C}$ topical hypothermia $(\mathrm{H})$ and $26^{\circ} \mathrm{C}$ topical hypothermia plus IPC $(\mathrm{H}+\mathrm{IPC})$. MAP, body temperature and bile flow were recorded each 15 minutes. Plasmatic injury markers and tissue antioxidant defenses were assessed after 120 minutes of reperfusion. Results: MAP and body temperature remained constant during all experiment. Bile flow returned to levels similar to controls after 45 minutes of reperfusion in the $\mathrm{H}$ and $\mathrm{H}+\mathrm{IPC}$ groups and increased significantly in comparison to the NI and IPC groups after 105 and 120 minutes. AST and ALT increased significantly in the normothermic groups in comparison to controls. TBARS levels decreased significantly in the H+IPC group in comparison to the other groups whereas Catalase levels increased significantly in the IPC group. SOD levels were significantly higher in the $\mathrm{H}$ group in comparison to all groups. Conclusion: The induction of $26^{\circ} \mathrm{C}$ topical hypothermia associated or not to IPC protected the ischemic liver against ischemia/reperfusion injuries and allowed an early recovery of the hepatic function.

Key words: Ischemia. Reperfusion. Ischemic Preconditioning. Hypothermia. Liver. Rats.
\end{abstract}

\section{RESUMO}

Objetivo: Avaliar os efeitos da hipotermia hepática tópica combinada ao pré-condicionamento isquêmico na proteção dos danos iniciais de isquemia e reperfusão. Métodos: Trinta e dois ratos Wistar foram submetidos à isquemia hepática parcial durante 90 minutos em Normotermia (IN), Pré-condicionamento Isquêmico (IPC), Hipotermia a $26^{\circ} \mathrm{C}(\mathrm{H})$ e Hipotermia a $26^{\circ} \mathrm{C}$ mais PCI (H+PCI). A PAM, a temperatura corporal e o fluxo biliar foram aferidos em intervalos de 15 minutos. Marcadores plasmáticos de danos hepáticos e as defesas antioxidantes foram avaliados após 120 minutos de reperfusão. Resultados: A PAM e a temperatura corporal permaneceram constantes durante o experimento. O fluxo biliar retornou a valores semelhantes ao grupo C nos grupos $\mathrm{H}$ e $\mathrm{H}+\mathrm{PCI}$ após 45 minutos de reperfusão e aumentou significativamente nos grupos H e H+PCI em comparação aos grupos IN e PCI após 105 e 120 minutos. Os níveis plasmáticos da AST e ALT demonstraram aumento significativo no grupo IN em comparação ao grupo C. Os níveis de TBARS diminuíram significativamente no grupo H+PCI em comparação aos grupos IN, PCI e H. Os níveis de Catalase aumentaram significativamente no grupo PCI em comparação aos grupos C, IN e H+PCI. Os níveis de SOD foram significativamente maiores no grupo H em comparação aos grupos C, IN, PCI e H+PCI. Conclusão: A hipotermia tópica protegeu o fígado isquêmico contra os danos de isquemia e reperfusão e permitiu uma recuperação precoce da função hepática.

Descritores: Isquemia. Reperfusão. Precondicionamento Isquêmico. Hipotermia. Fígado. Ratos. 


\section{Introduction}

Ischemia-reperfusion injury $(\mathrm{I} / \mathrm{R})$ is a major cause of morbidity and mortality in liver surgery and transplantation. In order to attenuate the deleterious effects of $I / R$, some strategies such as topical Hypothermia and IPC have been used with proven benefits ${ }^{1,2}$. The protective effect of hypothermia has been attributed to a reduction of liver metabolism and the subsequent decrease of oxygen requirement that occurs with a temperature decrease during the ischemia ${ }^{3}$. In addition, the prevention of liver injuries promoted by attenuation of oxidative stress and microcirculatory injury after the reperfusion also plays an important role ${ }^{3-5}$. Contrary to hypothermia applied through whole body temperature cooling or in situ perfusion cooling, topical hypothermia is a simple, fast, and low cost technique, which is not associated with hemodynamic imbalance and body temperature decrease ${ }^{2}$. There is growing evidence that even mild or moderate hypothermia evokes functional protection against I/R injury ${ }^{4-6}$. On the other hand, IPC is an inducible and potent endogenous mechanism by which repeated episodes of brief $\mathrm{I} / \mathrm{R}$ promote protection against subsequent sustained ischemia ${ }^{1}$. While a number of protective mediators have been identified such as adenosine $e^{7}$, nitric oxide ${ }^{8}$ or various kinases ${ }^{9,10}$, the triggering mechanism of protection remains unknown. One of the possible protective mechanisms is related to a reduction of oxidative stress $^{11,12}$. In the present study the authors assessed the occurrence of protective synergistic effects when both techniques are associated as well as the hepatocelular injuries, liver function and antioxidant defenses at the initial phase of the reperfusion.

\section{Methods}

This study was approved by HCPA-UFRGS Bioethical Committee of the Post-Graduation Group and follows the Council for International Organization of Medical Sciences (CIOMS) ethical code for animal experimentation and the principles of the Brazilian College on Animal Experimentation.

\section{Animals and experimental design}

Male Wistar rats $(\mathrm{n}=32)$ weighting $200-250 \mathrm{~g}$ were housed under standard environmental conditions with a 12-hour light/dark cycle. Animals were fasted overnight with unlimited access to water before their use in the experiments and were divided in five groups:

1. Control Group $(C)$. Animals underwent laparotomy and all preparation remaining without hepatic ischemia throughout the experiment, $(n=4)$.
2. Normothermic Ischemia Group (NI) Livers were subjected to ischemia of the median and lateral lobes for 90 minutes and subsequent reperfusion for 120 minutes, $(\mathrm{n}=7)$.

3. Ischemic Preconditioning Group (IPC) Ischemic preconditioning consisted of 10 minutes of warm ischemia and 10 minutes of reperfusion. Thereafter, the preconditioned liver lobes were exposed to 90 minutes of ischemia followed by 120 minutes of reperfusion, $(\mathrm{n}=7)$.

4. Hypothermia Group (H). Immediately after pedicle cross clamping, the median and left lateral liver lobes were cooled to $26^{\circ} \mathrm{C}$ for 90 minutes. Thereafter, the livers were reperfused for 120 minutes in normothermia, $(n=7)$.

5. Hypothermia plus Ischemic Preconditioning Group $(H+I P C)$. Ischemic preconditioning consisted of 10 minutes of warm ischemia and 10 minutes of reperfusion.

Immediately after pedicle cross clamping, the preconditioned liver lobes were cooled to

$26^{\circ} \mathrm{C}$ for 90 minutes. Thereafter, the livers were reperfused for 120 minutes in normothermia, $(n=7)$.

\section{Anesthesia and surgical procedures}

After 12 hours fasting, animals were anesthetized with ketamin sulfate $75 \mathrm{mg} / \mathrm{kg}$ (Vetbrands, Jacarei, Brazil) and xylazin $10 \mathrm{mg} / \mathrm{kg}$ (Vetbrands, Jacarei, Brazil) by intraperitoneal injection. One-third supplements of the initial dose were administered when necessary. Animals were placed in supine position on a heated pad for maintenance of body temperature. The rectal temperature was measured each 15 minutes and adjusted to $35.5^{\circ} \mathrm{C}-37.5^{\circ} \mathrm{C}$ when necessary by a heating lamp. A polypropylene catheter (Portex PE50 , Hythe, Kent, UK) was placed into the right carotid artery for recording of Mean Artery Pressure (MAP) (Sirecust 304D Siemens, Munich, Germany) every 15 minutes and continuous volume replacement with normal saline $(10 \mathrm{ml} / \mathrm{kg} / \mathrm{h})$. Oxygen $(0.5 \mathrm{l} / \mathrm{min})$ was administered by a face mask. The liver was exposed through an upper abdominal transverse incision, retractors were positioned on the rib cage and the liver was released from its ligaments. The bile duct was canulated (Portex PE-50, Hythe, Kent, UK) and brought outside by an incision in the inferior abdomen. Bile volumes were measured at 15 minutes intervals. To induce hepatic ischemia, the blood supply to the left and median liver lobes was interrupted by placement of an atraumatic microvascular clip (Medicon, Tuttlingen, Germany) at the level of the hepatic artery and portal vein, without inclusion of the correspondent biliary ducts. The un-occluded right and caudate lobes allowed outflow from the splanchnic circulation, thus avoiding venous congestion. After the start of liver ischemia, the 
top of the surgical table was elevated to 30 degrees and the median and lateral liver lobes carefully mobilized into a polyethylene concave device designed to isolate the liver in the abdominal cavity, according to previous descriptions ${ }^{13,14}$. A flexible intraparenchymal probe (IT-23, 0.5mm, Braintree Scientifics, Braintree, MA, USA) connected to a digital thermometer (Thermalert - TH5, Braintree Scientifics, Braintree, MA, USA) was inserted five millimeters deep within the central region of the ischemic left lateral lobe and the temperature was adjusted to $26^{\circ} \mathrm{C}$ by cooled saline solution superfusion in the $\mathrm{H}$ and $\mathrm{H}+\mathrm{IPC}$ groups. To avoid spillover of the cooled saline solution to the abdominal cavity and consecutive systemic cooling of the animal, a suction system was installed to remove fluid. IPC consisted of 10 minutes of warm ischemia and 10 minutes of reperfusion before the prolonged ischemia only in the IPC and H+IPC groups. After 90 minutes of ischemia, the clip was removed and the liver reperfused for 120 minutes. At the end of the experiment animals were killed by carotid exsanguination and blood samples were collected. Subsequently, the liver weight was determined and a segment of the previously ischemic lobes was cut in cubes, immediately frozen in liquid nitrogen and kept in a $-80^{\circ} \mathrm{C}$ freezer, whereas another fragment was fixed in $4 \%$ formaldehyde.

\section{Bile flow}

Bile samples were collected every $15 \mathrm{~min}$ by siphoning. Bile volume was determined gravimetrically, assuming a density of $1.0 \mathrm{~g} / \mathrm{ml}$, and the results were expressed as microliters per minute per gram of wet weight liver.

\section{Liver enzymes}

Blood samples were taken from the carotid artery at the end of the experiment, immediately centrifuged at $4000 \mathrm{Xg}$ for $10 \mathrm{~min}$, and stored at $-80^{\circ} \mathrm{C}$. Serum aspartate aminotransferase (AST) alanine aminotransferase (ALT) were measured by means of automated analyzer (Modular P800 Hitachi, Roche-Boehringer, Mannheim, Germany).

\section{Thiobarbithuric Acid Reactive Substances (TBARS)}

The determination of the TBARS was performed using the Buege and Aust method ${ }^{14}$. The liver was homogenized with tricloroacetic acid $10 \%$ and a solution of tiobarbituric acid $0.67 \%$ plus sodium sulfate $7.1 \%$. Afterwards, the composition was heated to $100^{\circ} \mathrm{C}$ for 30 minutes and then cooled in ice for 10 minutes. After that, n-butyl alcohol was added to the composition and the homogenate agitated for 30 seconds in a Vortex system and centrifuged $(2000 \mathrm{Xg}$ ) for $5 \mathrm{~min}$. The supernatant obtained, which is product of the reaction of the lipoperoxides was transferred to a plate for reading in a $535 \mathrm{~nm}$ wavelength spectrophotometer. The results were expressed in nanomoles per milligram of protein (nmol/ mg.prot).

\section{Catalase}

The activity of Catalase was evaluated according to the method described by Boveris and Chance ${ }^{16}$. Phosphate buffer 50 $\mathrm{mM}$ (ph 7.0) and $\mathrm{H}_{2} \mathrm{O}_{2}$ were added to the liver homogenate. The rate of decomposition of the $\mathrm{H}_{2} \mathrm{O}_{2}(0.3 \mathrm{M})$ added to the homogenate was determined by reading in a $240 \mathrm{~nm}$ wavelength spectrophotometer. The results were expressed in picomoles per milligram of protein (pmoles/mg.prot).

\section{Superoxide Dismutase (SOD)}

The activity of the antioxidant enzyme SOD was evaluated using a technique described by Kirby and Fridovich ${ }^{17}$. Glicyn buffer $50 \mathrm{mM}(\mathrm{pH} \mathrm{11.0)}$ and adrenalin were inserted into a plate of 96 wells containing liver homogenate. The ability of the SOD to inhibit the reaction of superoxide radical was determined by reading in a $480 \mathrm{~nm}$ wavelength spectrophotometer. The results were expressed in units of SOD per milligrams of protein (USOD/mg.prot).

\section{Statistics}

Data were analyzed for statistical significance by analysis of variance (One-way ANOVA or ANOVA on ranks) using a statistical software package (SigmaStat for Windows, Jandel Scientific, Erkath, Germany). Correlations were analyzed by Spearman coefficient. Data are given as Mean \pm Standard Error of the Mean (SEM) and $p$ values less than 0.05 were considered as significant.

\section{Results}

\section{MAP and body temperature}

In all groups, the MAP and body temperature remained constant over the whole experiment. There was no significant difference between animals subjected to topical hypothermia, normothermic ischemia, and sham-operated controls (Figure 1). 
MAP means ranged from $76.5 \pm 3.1 \mathrm{mmHg}$ to $83.8 \pm 1.8$ $\mathrm{mmHg}$ in the $\mathrm{C}$ group, $83.3 \pm 4.5 \mathrm{mmHg}$ to $101.0 \pm 5.8 \mathrm{mmHg}$ in the NI group, $86.3 \pm 3.2 \mathrm{mmHg}$ to $97.9 \pm 6.1 \mathrm{mmHg}$ in the IPC group, $82.6 \pm 4.4 \mathrm{mmHg}$ to $94.7 \pm 4.2 \mathrm{mmHg}$ in the H+IPC group and $84.7 \pm 5.0 \mathrm{mmHg}$ to $97.3 \pm 6.7 \mathrm{mmHg}$ in the $\mathrm{H}$ group.

Body temperature means ranged from $36.5 \pm 0.1^{\circ} \mathrm{C}$ to 37.0 $\pm 0.3{ }^{\circ} \mathrm{C}$ in the $\mathrm{C}$ group, $36.5 \pm 0.2{ }^{\circ} \mathrm{C}$ to $37.2 \pm 0.1{ }^{\circ} \mathrm{C}$ in the NI group, $36.5 \pm 0.1{ }^{\circ} \mathrm{C}$ to $37.1 \pm 0.2^{\circ} \mathrm{C}$ in the IPC group, $36.9 \pm 0.2^{\circ} \mathrm{C}$ to $37.2 \pm 0.2$ in the $\mathrm{H}+\mathrm{IPC}$ group and $35.8 \pm 0.5^{\circ} \mathrm{C}$ to $37.1 \pm 0.2^{\circ} \mathrm{C}$ in the $\mathrm{H}$ group.
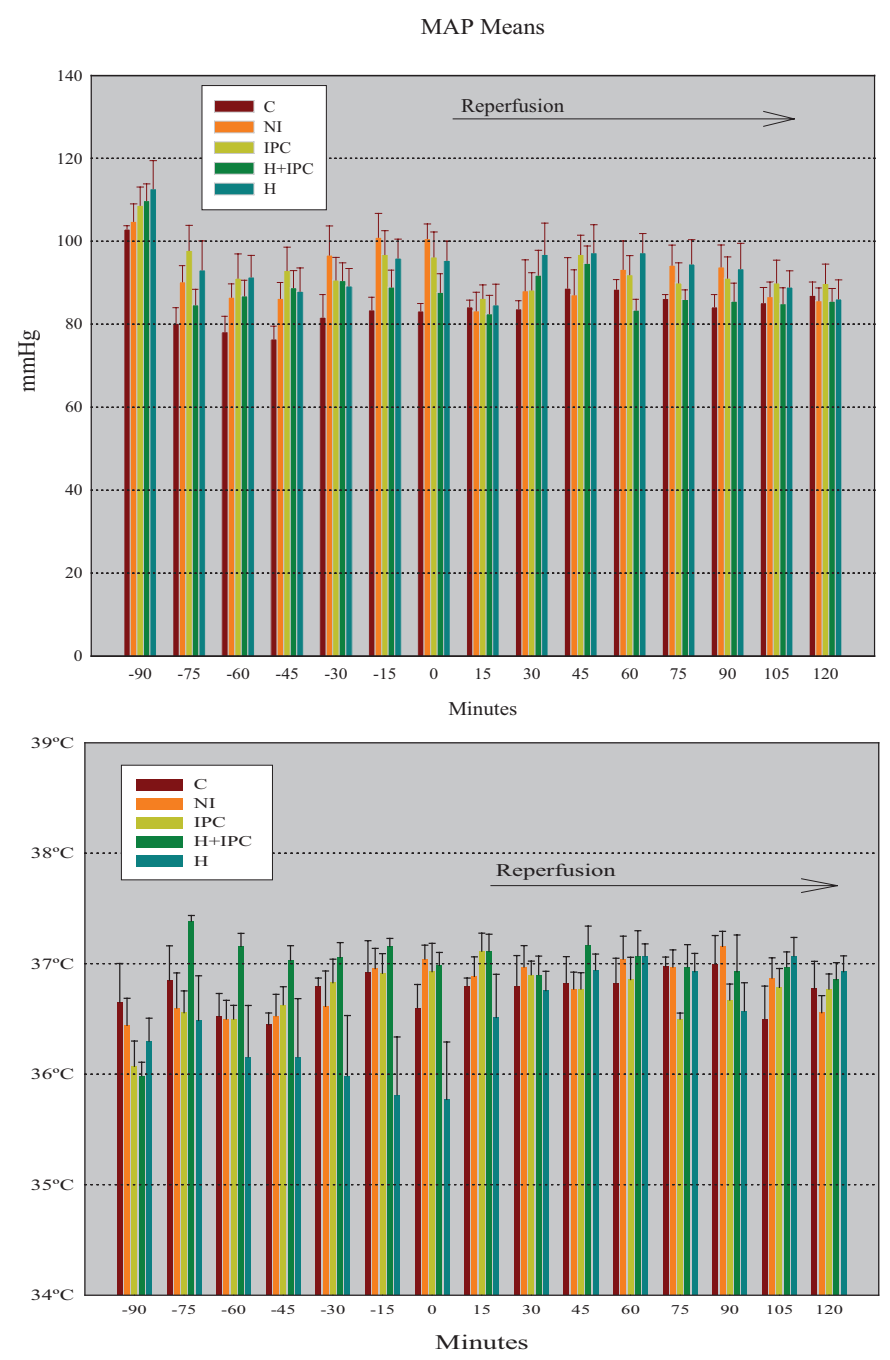

FIGURE 1 - Mean arterial pressure and body temperatures during the experiment.

\section{Liver enzymes}

Mean serum activities of AST and ALT in the C group were $279 \pm 36 \mathrm{IU} / \mathrm{L}$ and $107 \pm 40 \mathrm{IU} / \mathrm{L}$. After normothermic ischemia in the NI group, AST and ALT enzyme activities were significantly increased to $3910 \pm 1049 \mathrm{IU} / \mathrm{L}$ and $4660 \pm 1371 \mathrm{IU} / \mathrm{L}$, respectively ( $<<0.05$ vs. C group). After ischemic preconditioning in the IPC group AST and ALT mean levels were significantly increased to $4207 \pm 725 \mathrm{IU} / \mathrm{L}$ and $4086 \pm 832 \mathrm{IU} / \mathrm{L}$, respectively $(\mathrm{p}<0.05$ vs. C group). In contrast, after hypothermic ischemia in the $\mathrm{H}$ and $\mathrm{H}+\mathrm{IPC}$ groups the enzyme activities were not different from the sham group (Figure 2).


FIGURE 2 - AST and ALT levels at the end of reperfusion. $* \mathrm{p}<0.05$ vs. $\mathrm{C}$ group. Data expressed as Mean \pm SEM. One-way ANOVA, StudentNeumann-Keuls post hoc test.

At the end of reperfusion the mean serum levels of ALT in the $\mathrm{C}$ group were $107 \pm 40 \mathrm{IU} / \mathrm{L}$, whereas in the NI group were significantly increased to $4660 \pm 1371 \mathrm{IU} / \mathrm{L}$ ( $\mathrm{p}<0.05$ vs. C group). As in the NI group, in the IPC group the mean ALT levels were significantly increased to $4086 \pm 832 \mathrm{IU} / \mathrm{L}$ ( $\mathrm{p}<0.05$ vs. C group). In the $\mathrm{H}$ group the mean ALT levels were $1637 \pm 404 \mathrm{IU} / \mathrm{L}$, whereas in the H+IPC group the mean ALT levels were $2878 \pm 629$ IU/L (Figure 2).

\section{Bile flow}

Cross-clamping of the portal inflow reduced the bile flow in all groups in comparison to $\mathrm{C}$ group. However, after 90 minutes of ischemia, the bile flow output in the $\mathrm{H}$ and $\mathrm{H}+\mathrm{IPC}$ groups was significantly lower in comparison to the NI $(p<0.05$ and $p<0.05)$ and IPC $(\mathrm{p}<0.05$ and $\mathrm{p}<0.05)$ groups (Figure 3$)$. 


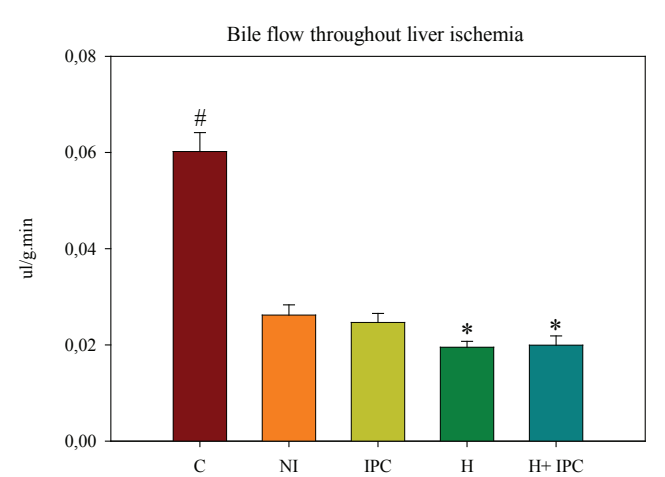

FIGURE 3 - Bile flow output during liver ischemia. ${ }^{*}<<0.01$ vs. all groups. ${ }^{*} \mathrm{p}<0.05$ vs. NI and IPC groups. Data expressed as Means \pm SEM. One-way ANOVA, Student-Neumann-Keuls post hoc test.

After the reperfusion, bile flow in the H+IPC and $\mathrm{H}$ groups returned to levels similar to the $\mathrm{C}$ group after 45 minutes of reperfusion and were increased significantly in comparison to the $\mathrm{NI}$ and IPC groups after 105 minutes $(\mathrm{p}<0.05$ and $\mathrm{p}<0.05)$ and 120 minutes ( $p<0.05$ and $p<0.05$ ) (Figure 4$)$.

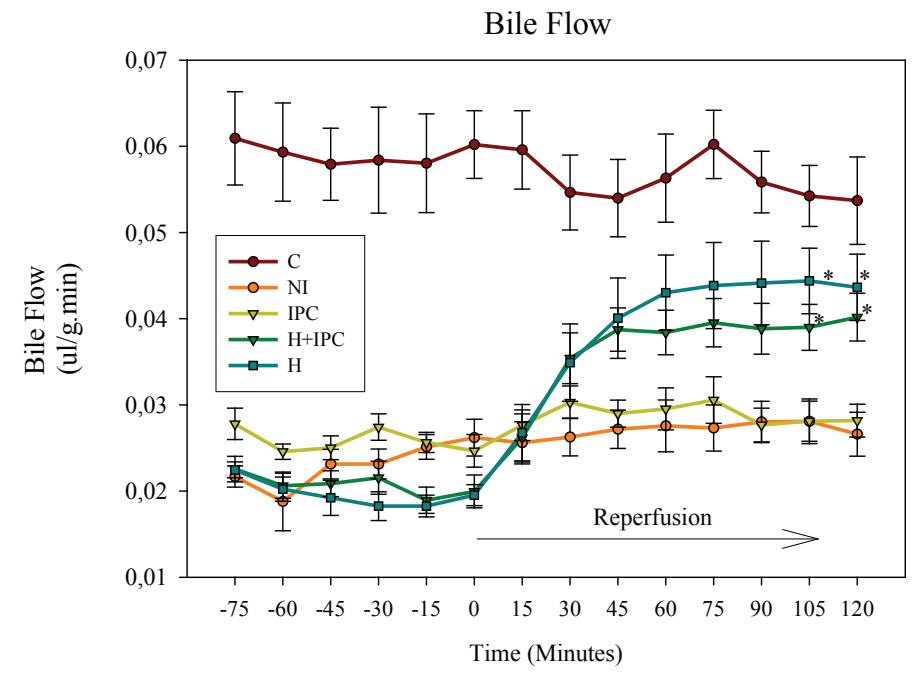

FIGURE 4 - Ischemia substantially reduces bile flow from the bilateral median and left lateral liver lobes. After reperfusion there was a recovery of bile flows in H+IPC and $\mathrm{H}$ groups (see the text). ${ }^{*} \mathrm{p}<0.05$ vs. NI and IPC groups. Data expressed as Mean \pm SEM, One-way ANOVA, StudentNeumann-Keuls post hoc test.

\section{TBARS, Catalase and SOD}

At the end of the experiment, lipid peroxidation of the membranes was evaluated in liver tissue. TBARS levels decreased significantly in the $\mathrm{H}+\mathrm{IPC}$ group in comparison to IN, IPC and $\mathrm{H}$ groups, but TBARS concentrations were not different to $\mathrm{C}$ group (Figure 4). The activities of the antioxidant enzymes Catalase and SOD were determined in liver tissue at the end of reperfusion.
Catalase showed a significant increased activity in the IPC group in comparison to the $\mathrm{C}, \mathrm{NI}$, and $\mathrm{H}+\mathrm{IPC}$ groups, but no difference with $\mathrm{H}$ group (Figure 5). In contrast, the antioxidant enzyme SOD showed significant increase in the $\mathrm{H}$ group in comparison to all groups (Figure 5).
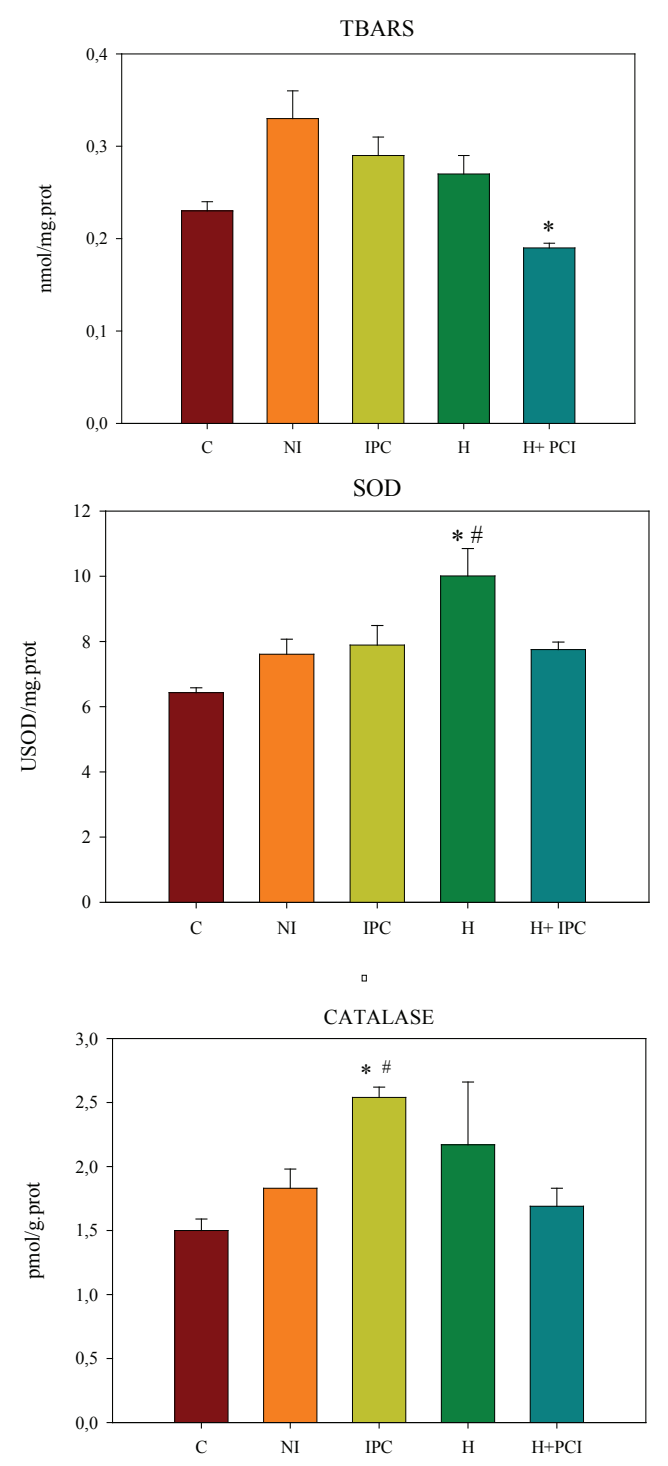

FIGURE 5 - (A) TBARS levels at the end of reperfusion. *p $<0.05$ vs. NI, IPC and H. (B) Superoxide dismutase levels at the end of reperfusion. ${ }^{*} \mathrm{p}<0.05$ vs. NI, IPC and H+IPC groups. ${ }^{*} \mathrm{p}=0.01$ vs. C. (C) Catalase levels at the end of reperfusion. ${ }^{*} \mathrm{p}<0.05$ vs. NI and H+IPC groups, ${ }^{*} \mathrm{p}<0.01$ vs. $\mathrm{C}$ group. Data are expressed as Mean \pm SEM. One-way ANOVA, StudentNeumann-Keuls post hoc test.

\section{Correlations}

In the $\mathrm{H}$ group there was a negative correlation between bile flow and liver enzymes AST and ALT $(r=-0.88, p<0.05$ and $r$ $=-0.87, \mathrm{p}<0.01$, respectively). A positive correlation was observed between TBARS and liver enzymes AST and ALT $(r=0.92, p<0.01$ 
and $\mathrm{r}=0.78, \mathrm{p}<0.05$, respectively).

\section{Discussion}

In the present study the combination of topical hypothermia and IPC in a model of ischemia and reperfusion was evaluated. Although both are considered important surgical tools of protection against ischemia and reperfusion injuries, but to the knowledge of the authors, this is the first report of the simultaneous use of these techniques on the liver, whereas this combination was already reported in brain and heart surgery ${ }^{18,19}$. The protective mechanisms are not completely understood, but the attenuation of the damage caused by radical oxygen species (ROS) generated after the reperfusion seems to be, at least in part, a mechanism found in both techniques ${ }^{6,12}$.

In addition, hypothermia possibly attenuates the inflammatory response by a reduction in neutrophil recruitment and prevention of the no reflow phenomenon ${ }^{4,5,21}$. Similar to observed by Kato et al. ${ }^{21}$ we verify that induction of topical hepatic hypothermia allowed a homogenous macroscopic perfusion of the ischemic liver lobes immediately after the reperfusion, but in the normothermic groups, several areas of heterogeneous perfusion were viewed. This macroscopic finding was consistent with other reports and possibly is related to an attenuation of the no reflow phenomenon after the reperfusion promoted by hypothermia ${ }^{4,14,21}$.

The induction of $26^{\circ} \mathrm{C}$ topical hepatic hypothermia was not associated to hemodynamic disturbances during the experiments and the whole body temperature was similar in all groups. Thus, any possible influence of the MAP and body temperature in the results obtained can be discarded. In line with these findings, others have demonstrated that topical hypothermia is safe and has no influence on the hemodynamics and animal temperature ${ }^{2-4,22,23}$. It has been suggested that maintenance of the temperature is the subject of extreme importance in experimental studies, since very low levels of transaminases have been reported without a clear demonstration of the body temperature, a fact that suggests that some studies could have been conducted under hypothermic conditions ${ }^{3}$. Recent evidences show that even a mild or moderate hypothermia is protective $\mathrm{e}^{3,24,25}$.

Bile flow has been considered a very sensitive parameter of the initial ischemia and reperfusion injuries and represents the dynamic function of the unaffected mass of hepatocytes, whereas other markers as transaminases show only severe damage in a restricted number of hepatocytes ${ }^{26,27}$. After the portal inflow occlusion, bile flow output presented substantial decrease in all groups. However, a significant bile flow decrease was demonstrated in the hypothermic groups $(\mathrm{H}$ and $\mathrm{H}+\mathrm{IPC})$ in comparison to normothermic groups (IN and IPC). This finding can be attributed to a lower metabolic rate of the hepatocytes promoted by $26^{\circ} \mathrm{C}$ topical hepatic hypothermia. As already demonstrated, bile flow is directly correlated to ATP synthesis and oxygen demanding ${ }^{3,28,29}$. In contrast to normothermic groups, the lower metabolic rate observed in the hypothermic groups allowed bile flow recovery. After 45 minutes of reperfusion, there was no difference in bile flow output between hypothermic groups and controls. This finding confirms the protective effect of the topical hepatic hypothermia on the energetic status of the hepatocytes. In line with this observation, Takahashi et $a l .{ }^{30}$ showed that the reoxygenation in hypothermic animals is related to a total recovery of the energetic status, whereas animals subjected to normothermic ischemia did not present recovery of the ATP synthesis. Subsequently, the bile flow showed progressive recovery only in hypothermic groups. After 105 and 120 minutes of reperfusion, hypothermic groups showed a restoring of the bile flow to levels similar to controls and additionally a significant difference with normothermic groups. These finding confirms that topical hepatic hypothermia at $26^{\circ} \mathrm{C}$ promotes an early recovery of the liver function. Similar to previous reports ${ }^{27}$, the application of IPC showed no improvement in bile flow after reperfusion, whereas the combination of hypothermia and IPC showed a significant recovery in the present study, a finding that substantiates the influence of the hypothermia in bile flow after the reperfusion.

After 90 minutes of ischemia and 120 minutes of reperfusion, liver concentrations of TBARS, which is a sensitive marker of cell membrane lipid peroxidation, showed significant decrease in the H+IPC group in comparison to other treatment groups. This finding confirms a synergistic effect when hypothermia and IPC are combined and demonstrates that both topical hepatic hypothermia at $26^{\circ} \mathrm{C}$ and IPC have influence on the injuries caused by the $\operatorname{ROS}^{5,14}$. This protection was possibly related to an inhibition of the superoxide radical release when hypothermia was applied, since the induction of topical hepatic hypothermia at $26^{\circ} \mathrm{C}$ allowed a significant preservation of the tissue SOD activity. A possible explanation to the protective effect of hypothermia could be related to a reduction of the activity of Kupffer cells, which are the mean source of superoxide radicals at the initial reperfusion or prevention of the mitochondrial integrity at reperfusion, another source of superoxide radicals ${ }^{31}$. On the other hand, IPC apparently had influence on the intracellular xanthine metabolism and prevention of hydrogen peroxides release, since IPC promoted a significant preservation of Catalase levels. Possible explanations to lower Catalase activity when hypothermia is applied might be related to a decrease of AMP hydrolysis and xanthine accumulation, as 
demonstrated in other studies ${ }^{4}$. Another possibility is related to the high antioxidant capacity of the hepatocytes. In a scenario of lower ROS release promoted by IPC or hypothermia, the antioxidant system could scavenge almost completely the ROS in liver tissue, as already demonstrated ${ }^{32}$. Thus, apparently topical hepatic hypothermia and IPC act in the liver oxidant system on different routes and compartments.

Liver enzymes showed a high variability in all groups. The $\mathrm{NI}$ and IPC groups presented a significant difference when compared to controls, whereas the $\mathrm{H}$ and $\mathrm{IPC}+\mathrm{H}$ groups remained similar to controls. This finding suggests a protection promoted by topical hypothermia. Consistent with this, a negative correlation between liver transaminases and bile flow and a positive correlation between transaminases and TBARS was found in the $\mathrm{H}$ group. This result corroborates our prior findings that topical hepatic hypothermia at $26^{\circ} \mathrm{C}$ attenuates I/R injuries in the present model. In contrast to most authors ${ }^{1,8,11,33}$, IPC did not show benefits in serum liver enzymes. This observation, however, is similar to reports that used IPC in aged and cirrhotic rats, in liver donors to transplant or under total vascular exclusion ${ }^{25,34-36}$. A possible explanation might be related to the protocol of 90 minutes of ischemia applied in this study, which could be beyond the limits of IPC protection. Vajdovà et al. ${ }^{37}$ have suggested that the time of liver ischemia is important to IPC exerts its effects. Our observations, however, suggest that IPC allowed maintenance of the antioxidant capacity, which is in agreement with other studies ${ }^{11,38}$.

Histopathological analysis after 120 minutes of reperfusion showed a significant difference between the groups IN and $\mathrm{C}$ and no difference between IN and the other groups (data not shown). Hypothermia and IPC failed to show significant improvement. However, the absence of severe morphological damage is consistent with the observations of other investigators that could not find substantial necrosis and apoptosis until later times of reperfusion ${ }^{39}$.

\section{Conclusion}

The induction of $26^{\circ} \mathrm{C}$ topical hepatic hypothermia associated or not to IPC protected the ischemic liver against ischemia/reperfusion injuries and allowed an early recovery of the hepatic function. Topical hepatic hypothermia is more effective than IPC in restoring the immediate injuries after prolonged ischemia.

\section{References}

1. Clavien PA, Selzner M, Rudiger HA, Graf R, Kadry Z, Rousson $\mathrm{V}$, Jochum W. A prospective randomized study in 100 consecutive patients undergoing major liver resection with versus without ischemic preconditioning. Ann Surg. 2003;238(6):843-50.

2. Yamanaka N, Yamanaka J, Tanaka T, Tanaka W, Yasui C, Ando T. Topical cooling assisted hepatic resection of segment 7 and 8 oriented by en-bloc interruption of the targeted portal pedicles. Hepatogastroenterology. 1999;46(25):417-25.

3. Behrends M, Hirose R, Serkova NJ, Coatney JL, Bedolli M, Yardi J, Park YH, Niemann CU. Mild hypothermia reduces the inflammatory response and hepatic ischemia/reperfusion injury in rats. Liver Int. 2006;26(6):734-41.

4. Khandoga A, Enders G, Luchting B, Axmann S, Minor T, Nilsson U, Biberthaler P, Krombach F. Impact of intraischemic temperature on oxidative stress during hepatic reperfusion. Free Radic Biol Med. 2003(8);35:901-9.

5. Zar HA, Lancaster JR, Jr. Mild hypothermia protects against postischemic hepatic endothelial injury and decreases the formation of reactive oxygen species. Redox Rep. 2000;5(5):303-10.

6. Zar HA, Tanigawa K, Kim YM, Lancaster JR, Jr. Mild therapeutic hypothermia for postischemic vasoconstriction in the perfused rat liver. Anesthesiology. 1999;90(4):1103-11.

7. Peralta C, Hotter G, Closa D, Prats N, Xaus C, Gelpi E, RosellòCatafau J. The protective role of adenosine in inducing nitric oxide synthesis in rat liver ischemia preconditioning is mediated by activation of adenosine A2 receptors. Hepatology. 1999;29(1):12632.

8. Peralta C, Hotter G, Closa D, Gelpi E, Bulbena O, Rosello-Catafau J. Protective effect of preconditioning on the injury associated to hepatic ischemia-reperfusion in the rat: role of nitric oxide and adenosine. Hepatology. 1997;25(4):934-7.

9. Brooks G, Hearse DJ. Role of protein kinase $\mathrm{C}$ in ischemic preconditioning: player or spectator? Circ Res. 1996;79(3):627-30.

10. Crenesse D, Laurens M, Gugenheim J, Heurteaux C, Cursio R, Rossi $\mathrm{B}$, Schmid-Alliana A. Intermittent ischemia reduces warm hypoxiareoxygenation-induced JNK(1)/SAPK(1) activation and apoptosis in rat hepatocytes. Hepatology. 2001;34(5):972-8.

11. Rüdiger HA, Graf R, Clavien PA. Sub-lethal oxidative stress triggers the protective effects of ischemic preconditioning in the mouse liver. J Hepatol. 2003;39(6):972-7.

12. Lee WY, Lee SM. Ischemic preconditioning protects post-ischemic oxidative damage to mitochondria in rat liver. Shock. 2005;24(4):3705.

13. Grezzana Filho TJM, Mendonça TB, Gabiatti, G, Kruel, CDP, Corso, CO. Topic liver hypothermia and ischemic preconditioning: a new model of ischemia and reperfusion in rats. Acta Cir. Bras. 2009;24(4):262-6.

14. Biberthaler P, Luchting B, Massberg S, Teupser D, Langer S, Leiderer $\mathrm{R}$, Krombach F, Messmer K. Ischemia at 4 degrees C: a novel mouse model to investigate the effect of hypothermia on postischemic hepatic microcirculatory injury. Res Exp Med (Berl). 2001;200(2):93-105.

15. Buege JA, Aust SD. Microsomal lipid peroxidation. Methods Enzymol. 1978;52(2):302-10.

16. Boveris A, Oshino N, Chance B. The cellular production of hydrogen peroxide. Biochem J. 1972;128(3):617-30.

17. Kirby TW, Fridovich I. A picomolar spectrophotometric assay for superoxide dismutase. Anal Biochem. 1982;127(2):435-40.

18. An J, Camara AK, Rhodes SS, Riess ML, Stowe DF. Warm ischemic preconditioning improves mitochondrial redox balance during and after mild hypothermic ischemia in guinea pig isolated hearts. Am J Physiol Heart Circ Physiol. 2005;288(6):H2620-7.

19. Lee YJ, Miyake S, Wakita H, McMullen DC, Azuma Y, Auh S, Hallenbeck JM. Protein SUMOylation is massively increased in hibernation torpor and is critical for the cytoprotection provided by ischemic preconditioning and hypothermia in SHSY5Y cells. J Cereb Blood Flow Metab. 2007;27(5):950-62. 
20. Kato A, Singh S, McLeish KR, Edwards MJ, Lentsch AB. Mechanisms of hypothermic protection against ischemic liver injury in mice. Am J Physiol Gastrointest Liver Physiol. 2002;282(4):G608-16.

21. Imakita M, Yamanaka N, Kuroda N, Kitayama Y, Okamoto E. Does topical cooling alleviate ischemia/reperfusion injury during inflow occlusion in hepatectomy? Results of an experimental and clinical study. Surg Today. 2000;30(9):795-804.

22. Vejchapipat P, Poomsawat S, Poovorawan Y, Proctor E, Pierro A. The effects of moderate hypothermia on energy metabolism and serum inflammatory markers during laparotomy. Pediatr Surg Int. 2006;22(1):66-71.

23. Dinant S, van Veen SQ, Roseboom HJ, van Vliet AK, van Gulik TM. Liver protection by hypothermic perfusion at different temperatures during total vascular exclusion. Liver Int. 2006;26(4):486-93.

24. Heijnen BH, Straatsburg IH, Gouma DJ, van Gulik TM. Decrease in core liver temperature with 10 degrees $\mathrm{C}$ by in situ hypothermic perfusion under total hepatic vascular exclusion reduces liver ischemia and reperfusion injury during partial hepatectomy in pigs. Surgery. 2003;134(5):806-17.

25. Shiratori Y, Kiriyama H, Fukushi Y, Nagura T, Takada H, Hai K, Kamii K. Modulation of ischemia-reperfusion-induced hepatic injury by Kupffer cells. Dig Dis Sci. 1994;39(6):1265-72.

26. Bilzer M, Gerbes AL. Preservation injury of the liver: mechanisms and novel therapeutic strategies. J Hepatol. 2000;32(3):508-15.

27. Patel S, Pachter HL, Yee H, Schwartz JD, Marcus SG, Shamamian P. Topical hepatic hypothermia attenuates pulmonary injury after hepatic ischemia and reperfusion. J Am Coll Surg. 2000;191(6):6506.

28. Niemann CU, Choi S, Behrends M, Hirose R, Noh J, Coatney JL, Roberts JP, Serkova NJ, Maher, JJ. Mild hypothermia protects obese rats from fulminant hepatic necrosis induced by ischemia-reperfusion. Surgery. 2006;140(3):404-12.

29. Vaquero J, Belanger M, James L, Herrero R, Desjardins P, Côtè J, Blei AT, Butterworth RF. Mild hypothermia attenuates liver injury and improves survival in mice with acetaminophen toxicity. Gastroenterology. 2007;132(1):372-83.

30. Nieuwenhuijs VB, de Bruijn MT, Schiesser M, Morphett A, Padbury RT, Barritt GJ. Ischemic preconditioning and intermittent ischemia preserve bile flow in a rat model of ischemia reperfusion injury. Dig Dis Sci. 2007;52(1):1159-67.

31. Schiesser M, Wittert A, Nieuwenhuijs VB, Morphett A, Padbury RT, Barritt GJ. Intermittent ischemia but not ischemic preconditioning is effective in restoring bile flow after ischemia reperfusion injury in the livers of aged rats. J Surg Res. 2008;(1):61-8.

32. Takahashi K, Morikawa S, Inubushi T, Nosaka S. Protective effects of moderate hypothermia on phosphoenergetic metabolism in rat liver during gradual hypoxia studied by in vivo $31 \mathrm{P}$ nuclear magnetic resonance spectroscopy. J Surg Res. 2004;117(1):323-8.

33. Peralta C, Bartrons R, Riera L, Manzano A, Xaus C, Gelpi E, RosellòCatafau J. Hepatic preconditioning preserves energy metabolism during sustained ischemia. Am J Physiol Gastrointest Liver Physiol. 2000;279(1):G163-71.

34. Adam R, Reynes M, Johann M, Morino M, Astarcioglu I, Kafetzis I. The outcome of steatotic grafts in liver transplantation. Transplant Proc. 1991;23(1):1538-40.

35. Azoulay D, Lucidi V, Andreani P, Maggi U, Sebagh M, Ichai P, Lemoine A, Adam R, Castaing D. Ischemic preconditioning for major liver resection under vascular exclusion of the liver preserving the caval flow: a randomized prospective study. J Am Coll Surg. 2006;202(2):203-11.

36. Pacheco EG, Gomes MC, Rodrigues GR, Campos W, Kemp R, Silva $\mathrm{O}$ de C. Effect of liver ischemic preconditioning in cirrhotic rats submitted to hepatic ischemia/reperfusion injury. Acta Cir Bras. 2006;21(Suppl 1):24-8.

37. Vajdovà K, Heinrich S, Tian Y, Graf R, Clavien PA. Ischemic preconditioning and intermittent clamping improve murine hepatic microcirculation and Kupffer cell function after ischemic injury. Liver Transplant. 2004;10(4):520-8.

38. Yuan GJ, Ma JC, Gong ZJ, Sun XM, Zheng SH, Li X. Modulation of liver oxidant-antioxidant system by ischemic preconditioning during ischemia/reperfusion injury in rats. World $\mathrm{J}$ Gastroenterol. 2005;11(12):1825-8.

39. Selzner N, Rudiger H, GrafR, Clavien PA. Protective strategies against ischemic injury of the liver. Gastroenterology. 2003;125(3):917-36.

\section{Acknowledgement}

To the staff of the Animal Experimentation Unit of the HCPA for technical assistance, in particular Mrs. Marta Justina Giotti Cioato and Fabíola Schons Meyer.

\section{Correspondence:}

Tomaz de Jesus Maria Grezzana Filho

Rua Irmão José Otão, 170/406

90035-060 Porto Alegre - RS Brasil

tomgrez@uol.com.br
Conflict of interest: none Financial source: CNPq and FIPE

Received: November 10, 2010

Review: January 12, 2011

Accepted: February 14, 2011 